\title{
3 B Rearerch Square \\ Heterogeneity of Tick Abundance and Infection with Zoonotic Pathogenic Bacteria in a Belgian Peri-Urban Forest
}

Raphael Rousseau ( $\sim$ raphael.rousseau@uclouvain.be)

Université Catholique de Louvain

Marcella Mori

Sciensano (Belgium)

\section{Benoît Kabamba}

Université Catholique de Louvain

Sophie O. Vanwambeke

Université Catholique de Louvain

\section{Research Article}

Keywords: Ixodes ricinus, peri-urban forest, applied ecology, tick-borne disease risk, Borrelia burgdorferi, Coxiella burnetii, Francisella tularensis.

Posted Date: March 7th, 2022

DOI: https://doi.org/10.21203/rs.3.rs-1408033/v1

License: (c) (i) This work is licensed under a Creative Commons Attribution 4.0 International License. Read Full License 


\section{Abstract \\ Background}

Forests are the primary habitats for Ixodes ricinus and harbor high tick populations, vectors of various pathogens. As such, they are often considered as a homogenous land cover harboring abundant tick populations. However, little is known about the heterogeneity in tick density within a peri-urban forest, where human exposure is high. The study aims to assess the micro-environmental factors that favor tick abundance and their infection with three pathogens, in a peri-urban forest.

\section{Methods}

Ticks were sampled 17 times in 2016 in seven locations of a peri-urban forest during the period of tick activity. Three zoonotic pathogens were screened, Borrelia burgdorferi s.I., Coxiella burnetii, and Francisella tularensis. The influences of micro-environmental factors on tick abundance and infected tick abundance were tested with multiple negative binomial generalized linear models.

\section{Results}

787 nymphs and 81 adult ticks were collected., resulting in densities of 6.61 nymphs and 0.68 adults per $10 \mathrm{~km}^{2}$. These densities were variable between the sites, ranging from 2.12 to 14.59 nymphs per $10 \mathrm{~m}^{2}$ and 0.24 to 1.29 adults per $10 \mathrm{~m}^{2}$. The prevalence of $B$. burgdorferi s.I. was estimated at 3.37\%. Coxiella burnetii was detected three times (1.36\%) and $F$. tularensis was not detected. Tick abundances were highest in deciduous forests, located in sandy and loamy-sand soils covered by dense vegetation not easily accessible to forest visitors. The temperature during the sampling also positively affected tick abundance. No variables were significant for the models for infected ticks.

\section{Conclusions}

Tick abundance was in the upper range of other estimated tick densities in Belgian forests. Borrelia infection prevalence was lower but the genospecies composition was similar to previous studies in Belgium. The assumption that forests are a homogenously suitable tick habitat is questioned and we underline the necessity to account for micro-environmental conditions and human exposure.

\section{Introduction}

Many emerging infectious diseases have a zoonotic origin [1]. Their occurrence depends on the probability of contact between pathogens, potential vectors and hosts [2]. Ticks are important vectors of pathogens in Western Europe [3, 4]. Studies on tick abundance, tick infections, and their drivers focus on two types of associations and factors: (i) the temporal variation with climatic and meteorological factors (e.g. [5, 6] and (ii) the spatial variation and physical with environmental factors (e.g. [5, 7-9]. Some studies considered both temporal and spatial aspects [10-12]. In Western Europe, the main tick vector is Ixodes ricinus. Its life cycle ranges from two to three years with three active stages (larva, nymph, and adult). This generalist species feeds on a broad range of vertebrates, including mammals, birds, and reptiles [13]. They take a single blood meal by stage and migrate down the litter to moult or to lay eggs. They spend extended periods off-host in the environment, e.g., woodlands or pastures, for questing, moulting and diapausing, which present a strong seasonal variation $[14,15]$. Forests are tick primary habitats and are often associated with high tick abundance at regional $($ e.g. $[11,16,17]$ and local scales (e.g. $[7,8,10,14])$. 
In this study, we focus on three tick-borne diseases (TBD) in a Belgian peri-urban forest: Lyme borreliosis, tularaemia and Q fever. Lyme borreliosis (LB) is the most widespread TBD in Western Europe [18, 19]. If untreated, an infection may result in skin, neurological, musculoskeletal, or cardiac complications $[18,20]$. This multi-systemic inflammatory disease is caused by spirochetes from the species complex Borrelia burgdorferi sensu lato $[19,20]$. This species complex contains several human pathogens, e.g., B. afzelii, B. garinii, B. burgdorferi sensu stricto, B. bavariensis and B. spielmanii [18, 20-22]. They are associated with different clinical symptoms $[18,23,24]$. Borrelia burgdorferi s.s. in the north-eastern United States is particularly arthritogenic [25]. Borrelia garinii and B. afzelii cause LB in Europe, the first one being associated with most typical Lyme neuroborreliosis cases, and the latter to less specific clinical symptoms and skin manifestations [18, 23]. The roles of the other genospecies are unclear $[18,26]$. In Belgium, the prevalence of $B$. burgdorferi s.l. in ticks collected from humans was estimated at $13.9 \%$ [27], and the incidence of LB at 103 per 100,000 inhabitants (95\% UI 87-120) [28]. Based on the annual number of hospitalizations and positive results of laboratory tests, there was no evidence of any increase in LB in Belgium between 2003 and 2012 [29].

Tularaemia is a disease with initial flu-like symptoms which can evolve towards serious clinical manifestations and significant mortality if untreated, occurring mainly in the Northern Hemisphere [30]. Several routes of infection exist, including skin contact with infected animals, ingestion of contaminated water, and arthropod bites [30, 31]. The route of infection and strain virulence lead to the different forms of the disease [30]. The ulceroglandular and glandular clinical forms are the most common in Central Europe and Belgium [32] and they frequently result from arthropod bite or animal contact. The agent of tularaemia is the gram-negative intracellular bacterium Francisella tularensis, a gammaProteobacteria of the Francisellaceae family [33]. Four subspecies have been identified: tularensis (type A), highly virulent and present in North America, holarctica (type B), in Central Europe and the whole northern hemisphere in general, mediasiatica, in Central Asia, and novicida [34]. Its main reservoirs are lagomorphs and rodents [33]. Tularaemia is rare in Belgium, but the number of detected cases is increasing, similarly with an increasing number of serological tests: 14 cases between 1950 and 2017, including 11 between 2010 and 2017 and 5 in 2017 [32].

Q fever is caused by the intracellular gram-negative bacterium Coxiella burnetii, a gamma(y)-Proteobacteria of the Legionella order $[35,36]$. This pathogen infects a wide range of hosts, including dogs, cats, bovine, deer, rodents, reptiles, fish, birds and ticks [37, 38]. In ruminants, the main clinical manifestations are reproduction disorders and abortions [36]. In humans, it can cause acute or chronic illness, but the diagnosis is challenging because most human infections are subclinical or give flu-like symptoms [37-39]. In Belgium, Q fever is widespread in Belgian domestic ruminants [40] and 25 cases of Q fever are confirmed yearly [41]. Infections generally occur through inhalation of $C$. burnetii contaminated aerosols in milk, faeces, urine and birth products or abortions from infected ruminants [37, 39, 42]. Coxiella burnetii was found in 40 tick species, and tick bites constitute another way of transmission, probably less important than the airborne one $[39,42]$. During three major outbreaks of Q fever in the Netherlands in 2007, 2008 and 2009, the prevalence of $C$. burnetii in questing I. ricinus was less than $0.2 \%$ [43] while Pacheco et al. [44] found a $C$. burnetii infection of $44.6 \%$ in Amblyomma tigrinum adult ticks in Argentina.

Variations in tick abundance $[21,45]$ and infection rates $[21,45,46]$ in endemic areas are key components of TBD risk assessment. Peri-urban forests are of particular interest, for both providing suitable habitats for ticks, that is, having a high level of hazard, and being visited intensively by humans, that is, generating high exposure $[14,19,47,48]$. Variability in tick abundance and pathogen prevalence within forests is less known but may be substantial $[8,10]$. The aim of this study is to analyse the heterogeneity of tick abundance and prevalence of three tick-borne pathogens (B. burgdorferi s.I., F. tularensis and $C$. burnetii) at the intra-seasonal time scale and within a peri-urban forest. We hypothesize that tick abundance is not homogeneous within a forest stand and is affected by within-forest heterogeneity.

\section{Material And Methods}

\section{Study area}


The Bois de Lauzelle is a peri-urban forest of nearly 200 hectares located across the municipalities of Wavre and OttigniesLouvain-la-Neuve (Fig. 1). This peri-urban region has a high and growing population density. The Bois de Lauzelle is bordered by a golf facility, the city of Louvain-la-Neuve, and high-speed roads. The forest belongs to and is managed by UCLouvain since 1970. It presents a diversity of local conditions, with an alternation of loamy and loamy-sand soils and altitudes ranging from 45 to 153 meters around the valley of the Blanc Ri River. The forest is dominated by deciduous trees, mainly beech and oak [49], and is legally protected by several statutes such as Natura 2000 (code BE31006) [50].

\section{[Insert Fig. 1 here] \\ Tick sampling}

Ticks were sampled in seven sampling units (SU) every two weeks from March 21st, 2016, to November 29th, 2016, resulting in 17 sampling events (SE). SUs were selected to contrast vegetation types found across the forest. A description of the Bois de Lauzelle and the SU is provided in an online interactive app (Additional file 1: Text 1). Each SU was a delimited area of $10 \mathrm{~m}^{2}(1 \mathrm{mX10m})$, dragged by the same collector, using a $1 \mathrm{~m}^{2}$-white flannel over the leaf litter, woodland scrub, or low vegetation. Dragging is the most common method for tick capture in the vegetation because of its costeffectiveness and its ease of implementation and replication among field workers [51]. However, it tends to underestimate absolute tick abundance and its efficiency also fluctuates with the time of the day and the undergrowth [52]. During each SE, we executed ten consecutive drags over the same SU in a rapid sequence. Consecutive drags give a better proxy of the true abundances and allow better between-sites comparisons [52]. Samplings were performed on dry and non-windy days between 9:00 AM and 12:00 AM. The flannel was changed whenever it became dirty or humid and was examined for ticks at the end of each drag. Nymph and adult ticks were sampled and counted, and ticks from the same SU were stored in alcohol. Larvae, found aggregated in the environment and rarely infesting humans, were not systematically sampled, and put in separate pools.

\section{Data preparation}

Tick life stage and species were identified under a Leica EZ4 binocular (X35), based on two conventional morphological identification keys $[53,54]$. We also used [55] to distinguish between three similar species found in Belgium, Ixodes ricinus, I. frontalis and I. arboricola. Ticks were washed in three consecutive baths with $70 \%$ alcohol and sterilized water and crushed individually with a sterilized loop in Eppendorf containing 200 $\mu$ l of Dulbecco's modified Eagle's medium (DMEM) cell culture medium. Then, they were grouped in pools of four $(50 \mu \mathrm{l} / \mathrm{each}$, for a total volume of $200 \mu \mathrm{l})$ when possible, considering that ticks from the same pool were sampled from the same SU and the same season. For practical reasons, nymphs and adult ticks were not put in separate pools.

\section{DNA extraction, sequencing, and PCR}

DNA was extracted from $100 \mu$ l pool medium (four ticks). The complete methods for DNA extraction and sequencing are explained elsewhere [56]. Several PCR assays were performed for the screening of ticks and the three tick-borne pathogens: B. burgdorferi s.I., F. tularensis, and C. burnetii: (i) SYBR Green real-time PCR on 5S and ITS2 genes to validate DNA extraction and confirm tick genus (Ixodes versus Dermacentor), (ii) TaqMan real-time (Light-Cycler® TaqMan® Master, Roche Diagnostics $\mathrm{GmbH}$, Germany) targeting C. burnetii insertion element IS1111 with previously described primers [57], (iii) TaqMan real-time (Light-Cycler ${ }^{\circledR}$ TaqMan ${ }^{\circledR}$ Master, Roche Diagnostics $\mathrm{GmbH}$, Germany) targeting Francisella (ISFtu primers) [58] and Francisella-like (FopA primers) [59], (iv) two qPCR targeting the Outer Surface Protein A gene (OspA) and the Borrelia flagellin gene (Fla). This method was adapted from [21]. The real-time PCR was done (Light-Cycler 480® SYBR Green I Master, Roche Diagnostics GmbH, Germany) instead of an end-point PCR and the identification of species was performed by Sanger sequencing on the Genetic Analyzer ABI 3730XL (Applied Biosystems, Invitrogen Life Technologies, Carlsbad, CA, USA), with the BigDye Terminator kit (Applied Biosystems). To achieve more consistent sequencing results, we used the universal M13 tailed primer attached to the locus-specific primers described by [21]. The obtained consensus sequences were analysed with the Basic Local Alignment Search Tool (BLAST) for species determination. 


\section{Response variables}

The effects of environmental local conditions were investigated for four response variables: density of nymphs (DON) of adults (DOA), of infected nymphs (DIN) and of adults (DIA). They were measured by counting the number of adults and nymphs sampled in the SU at each SU (ticks $/ 10 \mathrm{~m}^{2}$ ). DIN and DIA corresponded to the product of DOT and tick infection prevalence (TIP) by DON and DOA respectively. TIP is the probability that the bite is from an infected tick and was calculated following [60] (Eq. 1). This method estimates prevalence from pools, using a frequentist approach considering $100 \%$ sensibility and specificity and a fixed pool size. TIP, based on pools, was computed for each season for the seven SU.

$$
P=1-\left(1-\frac{x}{m}\right)^{1 / k} \quad \text { Equation } 1
$$

where $\mathrm{P}$ is the estimated prevalence, $\mathrm{k}$, the pool size, $\mathrm{x}$, the number of positive pools, and $\mathrm{m}$, the number of pools tested.

\section{Environmental variables}

We measured weather parameters in one place across all SU at each SE (temporal variables) using a HOBO U23 Pro v2 Data Logger placed at $130 \mathrm{~cm}$ above the ground close to SU.4. (Table 1). Ixodes ricinus is vulnerable to desiccation [5, 61], and temperature and relative humidity influence its survival, developments rates and activity periods $[5,17,62,63]$. Temperatures measured at $130 \mathrm{~cm}$ and $5 \mathrm{~cm}$ in a forest are often correlated [10,64]. 
Table 1

Descriptive statistics of response variables, site variables and temporal variables.

\begin{tabular}{|c|c|c|c|c|c|c|}
\hline Variable & Min & Mean & Max & Frequency (SU*SE) & Type & $\begin{array}{l}\text { Method of } \\
\text { collection }^{+}\end{array}$ \\
\hline \multicolumn{7}{|l|}{ Continuous Variables } \\
\hline $\begin{array}{l}\text { DON (nymphs sampled per } \\
\left.10 \mathrm{~km}^{2}\right)\end{array}$ & - & 6.61 & 44 & - & $\begin{array}{l}\text { Spatio- } \\
\text { temporal }\end{array}$ & Sampling \\
\hline $\begin{array}{l}\text { DOA (adults sampled per } \\
\left.10 \mathrm{~km}^{2}\right)\end{array}$ & - & 0.68 & 6 & - & $\begin{array}{l}\text { Spatio- } \\
\text { temporal }\end{array}$ & Sampling \\
\hline Temperature $\left({ }^{\circ} \mathrm{C}\right)$ & -1.94 & 12.89 & 22.91 & - & Temporal & Hobo \\
\hline Relative humidity (\%) & 47.59 & 85.04 & 100 & - & Temporal & Hobo \\
\hline Vegetation height $(\mathrm{cm})$ & 0 & 20.38 & 60 & - & $\begin{array}{l}\text { Spatio- } \\
\text { temporal }\end{array}$ & Sampling \\
\hline Slope percentage (\%) & 1.13 & 6.39 & 7.21 & - & Spatial & GIS \\
\hline $\begin{array}{l}\text { Distance to the forest edge } \\
\text { (m) }\end{array}$ & 38.61 & 190.43 & 398.84 & - & Spatial & GIS \\
\hline \multicolumn{7}{|l|}{ Categorical Variables } \\
\hline \multirow[t]{3}{*}{ Main undergrowth } & - & - & - & Brambles: $3 * 17=51$ & \multirow[t]{3}{*}{ Spatial } & \multirow[t]{3}{*}{ Sampling } \\
\hline & - & - & - & Grass: $3 * 17=51$ & & \\
\hline & - & - & - & Moss: $1 * 17=17$ & & \\
\hline \multirow[t]{2}{*}{ Soil texture class } & - & - & - & Loamy: 5*17 = 85 & \multirow[t]{2}{*}{ Spatial } & \multirow[t]{2}{*}{ GIS } \\
\hline & - & - & - & $\begin{array}{l}\text { Loamy-sand: } 2 * 17= \\
34\end{array}$ & & \\
\hline \multirow[t]{2}{*}{ Soil drainage class } & - & - & - & Excessive: $3 * 17=51$ & \multirow[t]{2}{*}{ Spatial } & \multirow[t]{2}{*}{ GIS } \\
\hline & - & - & - & $\begin{array}{l}\text { Favourable: } 4 * 17= \\
68\end{array}$ & & \\
\hline \multirow[t]{2}{*}{ Type of forest } & - & - & - & Deciduous: $5 * 17=85$ & \multirow[t]{2}{*}{ Spatial } & \multirow[t]{2}{*}{ GIS } \\
\hline & - & - & - & Coniferous: $2 * 17=34$ & & \\
\hline \multirow[t]{3}{*}{ Forest management } & - & - & - & $\begin{array}{l}\text { Pure high forest: } \\
4 * 17=68\end{array}$ & \multirow[t]{2}{*}{ Spatial } & \multirow[t]{2}{*}{ GIS } \\
\hline & - & - & - & $\begin{array}{l}\text { Mixed high forest: } \\
2^{*} 17=34\end{array}$ & & \\
\hline & - & - & - & Grass 1*17 = 17 & & \\
\hline \multirow[t]{3}{*}{ Season } & - & - & - & Spring: $7 * 5=35$ & \multirow[t]{3}{*}{ Temporal } & \multirow[t]{3}{*}{-} \\
\hline & - & - & - & Summer: $7 * 6=42$ & & \\
\hline & - & - & - & Fall: $7 * 6=42$ & & \\
\hline
\end{tabular}


Ixodes ricinus retreats in the leaf layer for transstadial development and when questing conditions are unfavourable [19, 65]. Tack et al. [66] found no effect of thinning on tick abundance, while shrub clearing decreases it. For each SU, we determined the main undergrowth (bramble, grass, or moss) once, and measured its height throughout the sampling season. Ticks are usually more abundant in deciduous forests compared to coniferous forests $[8,14,19,67]$. Forest management practices may also influence tick density [68]. Information of the forest stand type (coniferous or deciduous) and the forest management practice (coppicing, mixed or pure high forest) were extracted from existing data (forestry unit of the Earth and Life Institute of UCLouvain, personal communication).

Forest edge habitats are more suitable for several tick hosts $[8,62,69]$. In peri-urban environments, [70] also found significantly more nymphs at the woodland edge than in any other habitat. We measured, for each SU, the distance to the forest edge.

Soil characteristics (soil type, drainage, slope) may also affect tick abundance. In the United States, [71] found more I. scapularis in sandy and loamy-sand soils, compared to clay and loamy soils. Data on soil texture and drainage were extracted from the digital soil map of Wallonia [72]. We also calculated the mean slope percentage with a Digital Elevation Model at $20 \mathrm{~m}$ spatial resolution. Variables characterizing the SU (site variables) are static, except for vegetation height, measured in each SU across the samplings.

\section{Statistical analyses}

DON, DOA, DIN and DIA were tested for spatial autocorrelation with Moran's I test (R ape package, Paradis and Schliep, 2019). We performed Spearman's rho for rank correlations between DON, DOA, and TIP. Differences in DON, DOA, DIN, and DIA between SU, types of soil, undergrowth and seasons were tested using non-parametric Kruskal-Wallis (K-W) tests. We calculated the diversity of Borrelia genospecies with the Shannon diversity Index (R vegan package [74]). This index is one of the most commonly used diversity indexes in ecology [75].

The dataset has a nested structure with SE nested within SU, and thus required a multi-level analysis approach. We built two types of models: (i) temporal models, considering the weather and vegetation height, with SU as a random factor, (ii) site models, using SE as a random factor. After standardization of the explanatory variables, we created two models for the four response variables DON, DOA, DIN and DIA resulting in eight generalized linear mixed models (GLMM), using the Ime4 $R$ package [76]. DIN and DIA models were not computed because TIP was calculated for the seasons, which added collinearity in the data. The likelihood ratio of a fitted Poisson model against a fitted negative binomial model indicated that the data were overdispersed which can lead to inflated and biased F-values [77, 78]. We used Vuong's non-nested tests (pscl R package [79]) to compare Poisson models with negative binomial models, and with their zero-inflated versions. Spearman's rank correlations were performed between the predictors to select non-correlated explanatory variables (Spearman $|\mathrm{rho}|<0.90$ ) [78]. Then, we performed bivariate regression for all dependent variables. We built the multivariate GLMM by introducing the variables significant in the bivariate analysis at $\mathrm{P}<=0.15$, using a stepwise backward procedure. We only kept variables significant at $\mathrm{P}<=0.05$ in the final models. Interactions between the remaining variables were tested. All models were compared with the Akaike's Information Criterion (AIC), considering two models with differences of AIC smaller than $|2|$ as equivalent. We checked the residuals for heteroscedasticity and spatial autocorrelation [80]. All statistical analyses were conducted in R 3.6.3 [81].

\section{Results}

\section{Descriptive statistics}


954 Ixodes ticks were sampled: 86 larvae, 787 nymphs, 37 males and 44 females (Additional file 2: Dataset S1). Larvae, not systematically sampled, were not further analysed. All nymphs and adults were Ixodidae, 854 I. ricinus, 13 I. frontalis and one I. ventalloi. DON and DOA were estimated at 6.61 nymphs and 0.68 adults per $10 \mathrm{~m}^{2}$ (Table 2). DON varied from 2.12 (SU.1) to 14.59 (SU.2), and DOA from 0.29 (SU.3) to 1.29 (SU.1 and SU.2). The mean percentage of adults by SU was 9.33\%, with SU.1 having the highest percentage (37.93\%). Nymphs were absent from 25 samplings, and adults from 70.

Table 2

Number of Ixodes ticks sampled per Sampling Unit (SU).

\begin{tabular}{|c|c|c|c|c|c|c|c|c|c|c|c|}
\hline \multirow[b]{2}{*}{ SU } & \multicolumn{2}{|c|}{$\begin{array}{l}\text { Spring (5 } \\
\text { samplings) }\end{array}$} & \multicolumn{2}{|c|}{$\begin{array}{l}\text { Summer (6 } \\
\text { samplings) }\end{array}$} & \multicolumn{2}{|c|}{$\begin{array}{l}\text { Fall (6 } \\
\text { samplings) }\end{array}$} & \multirow[t]{2}{*}{ DON } & \multirow[t]{2}{*}{ DOA } & \multirow[t]{2}{*}{ TIP } & \multirow[t]{2}{*}{ DIN } & \multirow[t]{2}{*}{ DIA } \\
\hline & N.N. & N.A. & N.N. & N.A. & N.N. & N.A. & & & & & \\
\hline SU.1 & 18 & 15 & 17 & 7 & 1 & 0 & $\begin{array}{l}2.12 \\
(2.34)\end{array}$ & $\begin{array}{l}1.29 \\
(1.45)\end{array}$ & $\begin{array}{l}11.99 \\
(6.32)\end{array}$ & $\begin{array}{l}0.28 \\
(0.32)\end{array}$ & $\begin{array}{l}0.15 \\
(0.17)\end{array}$ \\
\hline SU.2 & 95 & 5 & 116 & 12 & 37 & 5 & $\begin{array}{l}14.59 \\
(10.09)\end{array}$ & $\begin{array}{l}1.29 \\
(1.57)\end{array}$ & $\begin{array}{l}1.48 \\
(2.41)\end{array}$ & $\begin{array}{l}0.18 \\
(0.18)\end{array}$ & $\begin{array}{l}0.02 \\
(0.03)\end{array}$ \\
\hline SU.3 & 31 & 1 & 30 & 3 & 10 & 1 & $\begin{array}{l}4.18 \\
(3.68)\end{array}$ & $\begin{array}{l}0.29 \\
(0.59)\end{array}$ & $\begin{array}{l}11.99 \\
(6.32)\end{array}$ & $\begin{array}{l}0.42 \\
(0.34)\end{array}$ & $\begin{array}{l}0.04 \\
(0.08)\end{array}$ \\
\hline SU.4 & 97 & 4 & 24 & 4 & 10 & 1 & $\begin{array}{l}7.71 \\
(11.75)\end{array}$ & $\begin{array}{l}0.53 \\
(0.87)\end{array}$ & $\begin{array}{l}2.99 \\
(3.38)\end{array}$ & $\begin{array}{l}0.20 \\
(0.39)\end{array}$ & $\begin{array}{l}0.01 \\
(0.02)\end{array}$ \\
\hline SU.5 & 39 & 1 & 27 & 3 & 0 & 0 & $\begin{array}{l}3.88 \\
(5.11)\end{array}$ & $\begin{array}{l}0.24 \\
(0.44)\end{array}$ & $\begin{array}{l}1.42 \\
(2.36)\end{array}$ & $\begin{array}{l}0.05 \\
(0.10)\end{array}$ & $\begin{array}{l}0.01 \\
(0.01)\end{array}$ \\
\hline SU.6 & 26 & 2 & 32 & 4 & 2 & 0 & $\begin{array}{l}3.53 \\
(4.37)\end{array}$ & $\begin{array}{l}0.35 \\
(0.49)\end{array}$ & $\begin{array}{l}1.50 \\
(2.43)\end{array}$ & $\begin{array}{l}0.06 \\
(0.24)\end{array}$ & $\begin{array}{l}0.00 \\
(0.00)\end{array}$ \\
\hline SU.7 & 101 & 7 & 60 & 4 & 14 & 2 & $\begin{array}{l}10.29 \\
(9.85)\end{array}$ & $\begin{array}{l}0.76 \\
(1.30)\end{array}$ & $\begin{array}{l}3.95 \\
(3.86)\end{array}$ & $\begin{array}{l}0.41 \\
(0.43)\end{array}$ & $\begin{array}{l}0.03 \\
(0.05)\end{array}$ \\
\hline Total & 407 & 35 & 306 & 37 & 74 & 9 & $\begin{array}{l}6.61 \\
(8.48)\end{array}$ & $\begin{array}{l}0.68 \\
(1.11)\end{array}$ & $\begin{array}{l}3.71 \\
(3.75)\end{array}$ & $\begin{array}{l}0.22 \\
(0.33)\end{array}$ & $\begin{array}{l}0.02 \\
(0.09)\end{array}$ \\
\hline \multicolumn{12}{|c|}{$\begin{array}{l}\text { Data represent the number of ticks collected in spring (March-May), summer (June-August) and fall (September- } \\
\text { November), the density of nymphs (DON), of adults (DOA), tick infection prevalence (TIP) and density of infected } \\
\text { nymphs (DIN) and adults (DIA). Densities were calculated as the mean (standard error) number of ticks per } 10 \mathrm{~m}^{2} \text {, and } \\
\text { TIP in percentages. SU = sampling units; N.N. = number of nymphs; N.A. = number of adults. }\end{array}$} \\
\hline
\end{tabular}

[Insert Table 2 here]

Nymphs and adults were grouped in 221 pools. B. burgdorferi s.l. was detected in 31 pools (12.81\%) from in all SU and during the three seasons (Additional file 3: Dataset S2). The estimated prevalence was $3.71 \%(\mathrm{SE}=3.75)$ and increased through the seasons, $2.35 \%$ ( $S E=3.02)$ in spring, 4.29\% (SE = 4.01) in summer and $8.26 \%(S E=5.40)$ in fall. The highest prevalences were found in SU.1 and SU.3 (11.99\%) which are close to a cub scout's meeting place and trails. Six Borrelia genospecies were identified: Borrelia afzelii was dominant (18 isolations), followed by B. garinii (6) and B. burgdorferi s.s. (4). Borrelia bavariensis, B. valaisiana, and B. spielmanii were only isolated once (Table 3). SU.3 and 
Table 3

Borrelia genospecies diversity by SU.

\begin{tabular}{|c|c|c|c|c|c|c|c|c|c|}
\hline \multirow[t]{2}{*}{ SU } & \multirow{2}{*}{$\begin{array}{l}\text { B. } \\
\text { Shannon } \\
\text { index }\end{array}$} & \multirow{2}{*}{$\begin{array}{l}B . \\
\text { species } \\
\text { richness }\end{array}$} & \multicolumn{7}{|c|}{ Borrelia species abundance } \\
\hline & & & $\begin{array}{l}\text { B. } \\
\text { burgdorferi } \\
\text { s.l. }\end{array}$ & $\begin{array}{l}\text { B. } \\
\text { afzelii }\end{array}$ & $\begin{array}{l}\text { B. } \\
\text { bavariensis }\end{array}$ & $\begin{array}{l}\text { B. } \\
\text { burgdorferi } \\
\text { s.s. }\end{array}$ & $\begin{array}{l}\text { B. } \\
\text { garinii }\end{array}$ & $\begin{array}{l}\text { B. } \\
\text { spielmanii }\end{array}$ & $\begin{array}{l}\text { B. } \\
\text { valaisiana }\end{array}$ \\
\hline SU.1 & 0.87 & 3 & 6 & 4 & 0 & 1 & 1 & 0 & 0 \\
\hline SU.2 & 0.56 & 2 & 4 & 3 & 0 & 1 & 0 & 0 & 0 \\
\hline SU.3 & 1.49 & 5 & 8 & 3 & 1 & 1 & 2 & 0 & 1 \\
\hline SU.4 & 0.56 & 2 & 4 & 3 & 0 & 1 & 0 & 0 & 0 \\
\hline SU.5 & 0 & 1 & 1 & 0 & 0 & 0 & 0 & 1 & 0 \\
\hline SU.6 & 0 & 1 & 1 & 0 & 0 & 0 & 1 & 0 & 0 \\
\hline SU.7 & 0.6 & 2 & 7 & 5 & 0 & 0 & 2 & 0 & 0 \\
\hline
\end{tabular}

SU.1 presented the highest diversity in the number of genospecies (five and three respectively), and of isolations (8 and 6). SU.5 and SU.6 had the lowest diversity with only one genospecies isolated (B. spielmanii and B. garinii). All detected genospecies but $B$. spielmanii were present in SU.3. Coxiella burnetii was only detected in three pools $(0.90 \%)$, one from SU.1 (in spring) and two from SU.2 (in summer). Francisella tularensis and Francisella-like bacteria were not detected.

[Insert Table 3 here]

No spatial autocorrelation was detected for DON, DIN and DIA in each SU, but DOA was spatially autocorrelated $(p=0.04)$ (Additional file 4, Table S1). DON varied significantly across the seven SU (Kruskal-Wallis H=24.49, $\mathrm{P}=0.0004$ ), seasons $(H=41.97, P<0.0001)$ and according to the undergrowth $(H=7.96, P=0.019)$, soil types $(H=9.64, P=0.019)$ and drainage categories $(H=3.96, P=0.047)$ (Additional file 4, Table S2). DON was higher in spring, in brambles, in loamy-sand soils and in soils with favourable drainage. We found significant correlations between DON and DOA (Spearman's rank correlation rs $=0.43, \mathrm{P}<0.0001)$, DON and DIN ( $r s=0.55, \mathrm{P}<0.0001)$, and DOA and DIA ( $r s=0.80, \mathrm{P}<0.0001$ ), but not between DON and TIP (rs= $-0.13, P=0.155)$, and DOA and TIP ( $r s=0.05, P=0.559)$.

DON was higher in spring $\left(11.60 \pm 10.99\right.$ nymphs $\left./ 10 \mathrm{~m}^{2}\right)$ than in summer $(7.31 \pm 7.10)$ and fall $(1.76 \pm 3.24)$. DOA was similar in spring $\left(0.97 \pm 1.32\right.$ adults $\left./ 10 \mathrm{~m}^{2}\right)$ and summer $(0.90 \pm 1.25)$, but lower in fall $(0.21 \pm 0.47)$. All sites reached their maximum abundance before July (Fig. 2). SU with low tick abundance, SU.1, SU.3, SU.5 and SU.6 had less variability ( mean $=3.43$, standard deviation $=4.00)$ than SU with high tick abundance, SU.2, 4 and 7 (mean = 10.83, standard deviation $=10.78$ ). SU.2 and SU.7 were covered by dense undergrowth. SU.4, located in a grassy area in the forest, had high DON in spring $\left(1.92 / 10 \mathrm{~m}^{2}\right)$, and low in summer (0.33) and fall $(0.23)$.

\section{[Insert Fig. 2 here]}

There were correlations but no multicollinearity between environmental predictors (Additional file 4, Figure S1). The highest absolute Spearman's correlation coefficient rs was $-0.41(P<0.001)$ between slope and vegetation height. DON was positively correlated with vegetation height $(r s=0.46, P<0.0001)$ and temperature $(r s=0.28, P=0.002)$, and negatively correlated with relative humidity $(r s=-0.41, P<0.0001)$ and slope $(r s=-0.21, P=0.020)$. There was no correlation with distance to forest edge ( $r s=0.05, P=0.554)$. DOA was positively correlated with vegetation height $(r s=0.31, P=0.0005)$ 
and temperature ( $r s=0.25, P=0.005)$, and negatively correlated with relative humidity $(r s=-0.24, P=0.007)$ and distance to forest edge ( $r s=-0.21, P=0.024)$. There was no correlation with slope $(r s=0.06, P=0.532)$.

\section{Mixed-level modelling}

For the nymph and the adult models, Vuong's test suggested the use of a negative binomial model over Poisson $(Z=5.717$, $P<0.0001$ and $Z=1.789, P=0.0368$ respectively), and zero-inflated Poisson $(Z=4.565, P<0.0001$ and $Z=1.783, P=0.0373$ respectively). There were no significant differences between the negative binomial model and their zero-versions $(Z=0.316$, $P=0.3761$ and $Z=0.996, P=0.1597$ respectively) (Additional file 4, Table S3). The simplest distribution (negative binomial) was used. The temporal GLM indicated DON and DOA were significantly higher in spring than in fall $(P<0.001)($ Tables 45). They were also significantly positively associated with temperature $(P<0.001$ for $D O N$ and $<0.05$ for $D O A)$, and $D O N$ was negatively with relative humidity $(P<0.05)$.

Table 4

Summary of negative binomial temporal mixed models for DON.

\section{Bivariate models \\ Best AIC multivariate model}

\begin{tabular}{|c|c|c|c|c|c|}
\hline Fixed effects & Estimate & $\begin{array}{l}\text { Standard } \\
\text { Error }\end{array}$ & $P$ & Estimate & Standard Error \\
\hline
\end{tabular}

\section{Season}

(compared to spring)

\begin{tabular}{lllllll} 
Summer & -0.49 & 0.20 & $0.0168(*)$ & -1.51 & 0.36 & $<0.0001(* \star *)$ \\
Fall & -2.05 & 0.23 & $\begin{array}{l}<0.0001 \\
(\star \star \star)\end{array}$ & -2.52 & 0.31 & $<0.0001(* \star *)$ \\
Temperature & 0.35 & 0.15 & $0.0152(*)$ & 0.67 & 0.17 & $<0.0001(* \star *)$ \\
\hline Relative Humidity & -0.44 & 0.14 & $0.0013(* *)$ & 0.28 & 0.14 & $0.0378(*)$ \\
Vegetation Height & 0.70 & 0.17 & $\begin{array}{l}<0.0001 \\
(\star \star \star)\end{array}$ & - & - & -
\end{tabular}

\begin{tabular}{lll} 
Random effects & Variance & Standard deviation \\
\hline SU. Intercepts & 0.39 & 0.63
\end{tabular}

The best AIC multivariate model $(\mathrm{AIC}=618.86)$ was preferred over the null model $(\mathrm{AIC}=687.17), \mathrm{X}^{2}=76.31(\mathrm{P}=1.05 \mathrm{e}-$ 15). $P<0.001^{\prime \prime} \star * \star^{\prime} ; P<0.01^{\prime \prime} * *^{\prime} ; P<0.05^{\prime \prime} \star^{\prime}$. 
Table 5

summary of negative binomial temporal mixed models for the DOA.

\begin{tabular}{|c|c|c|c|c|c|c|}
\hline & \multicolumn{3}{|c|}{ bivariate models } & \multicolumn{3}{|c|}{ Best AIC multivariate model } \\
\hline & Estimate & $\begin{array}{l}\text { Standard } \\
\text { Error }\end{array}$ & $\mathbf{P}$ & Estimate & $\begin{array}{l}\text { Standard } \\
\text { Error }\end{array}$ & $\mathbf{P}$ \\
\hline \multicolumn{7}{|l|}{ Fixed effects } \\
\hline \multicolumn{7}{|c|}{$\begin{array}{l}\text { Season (compared to } \\
\text { Spring) }\end{array}$} \\
\hline Summer & -0.03 & 0.28 & 0.9136 & -0.57 & 0.34 & 0.09 \\
\hline Fall & -1.50 & 0.41 & $\begin{array}{l}0.0002 \\
(\star \star \star)\end{array}$ & -1.52 & 0.41 & $0.0002(\star \star \star)$ \\
\hline Temperature & 0.45 & 0.15 & $0.0033(\star \star)$ & 0.48 & 0.19 & $0.0115\left(^{\star}\right)$ \\
\hline Relative Humidity & -0.36 & 0.12 & $0.0024(\star \star)$ & - & - & - \\
\hline Vegetation height & 0.65 & 0.41 & $\begin{array}{l}0.0003 \\
(\star \star \star)\end{array}$ & - & - & - \\
\hline Random effects & & & & Variance & Std.Dev & \\
\hline SU. Intercepts & & & & 0.28 & 0.53 & \\
\hline
\end{tabular}

[Insert Table 4 here]

The spatial GLM indicated significant differences in DON and DOA between SU in different undergrowth, forest management (Table 6-7). They were higher in brambles and in pure high forests. DON was also higher in deciduous forests compared to coniferous forests $(P<0.001)$, in brambles compared to grass and moss $(P<0.001)$, and in soils with favourable drainage compared to excessive drainage $(P<0.001)$. 
Table 6

Summary of the negative binomial spatial mixed model for DON.

\begin{tabular}{|c|c|c|c|c|c|c|}
\hline \multirow[b]{2}{*}{ Fixed effects } & \multicolumn{2}{|c|}{ Bivariate models } & \multicolumn{3}{|c|}{ Best AIC multivariate model } & \multirow[b]{2}{*}{$\mathbf{P}$} \\
\hline & Estimate & $\begin{array}{l}\text { Standard } \\
\text { Error }\end{array}$ & $\mathbf{P}$ & Estimate & $\begin{array}{l}\text { Standard } \\
\text { Error }\end{array}$ & \\
\hline \multicolumn{7}{|c|}{$\begin{array}{l}\text { Forest management (compare to Mixed } \\
\text { High Forest) }\end{array}$} \\
\hline Pure High Forest & 0.69 & 0.23 & $\frac{0.0025}{(* \star)}$ & -0.78 & 0.32 & $\begin{array}{l}0.0160 \\
(*)\end{array}$ \\
\hline Grass & 0.49 & 0.32 & 0.1303 & 2.48 & 0.40 & $\begin{array}{l}<0.0001 \\
(* \star *)\end{array}$ \\
\hline \multicolumn{7}{|c|}{ Forest type (compared to coniferous) } \\
\hline Deciduous & 0.40 & 0.22 & 0.0751 & - & - & - \\
\hline \multicolumn{7}{|c|}{ Undergrowth (compared to brambles) } \\
\hline Grass & -0.85 & 0.20 & $\begin{array}{l}<0.0001 \\
(\star \star \star)\end{array}$ & -1.87 & 0.28 & $\begin{array}{l}<0.0001 \\
(\star \star \star)\end{array}$ \\
\hline Moss & -1.07 & 0.29 & $\begin{array}{l}0.0003 \\
(* \star *)\end{array}$ & 0.79 & 0.32 & 0.0734 \\
\hline Vegetation height & 0.41 & 0.12 & $\begin{array}{l}0.0006 \\
(* \star *)\end{array}$ & & & \\
\hline \multicolumn{7}{|c|}{ Soil Type (compared to loamy) } \\
\hline Loamy-Sand & 0.87 & 0.20 & $\begin{array}{l}<0.0001 \\
(* * \star)\end{array}$ & - & - & - \\
\hline \multicolumn{7}{|c|}{ Soil drainage (compared to excessive) } \\
\hline favourable & 0.63 & 0.20 & $\begin{array}{l}0.0018 \\
(* *)\end{array}$ & 2.111 & 0.410 & $\begin{array}{l}<0.0001 \\
(* \star \star)\end{array}$ \\
\hline Slope percentage & -0.34 & 0.10 & $\begin{array}{l}0.0009 \\
(* \star *)\end{array}$ & - & - & - \\
\hline Distance to forest edge & -0.04 & 0.11 & 0.6894 & - & - & - \\
\hline Random effects & & & & Variance & $\begin{array}{l}\text { Standard } \\
\text { Deviation }\end{array}$ & \\
\hline SU. Intercepts & & & & 1.63 & 1.28 & \\
\hline
\end{tabular}


Table 7

Summary of the negative binomial spatial mixed model for the DOA.

\begin{tabular}{|c|c|c|c|c|c|c|}
\hline \multirow[b]{2}{*}{ Fixed effects } & \multicolumn{2}{|c|}{ Bivariate models } & \multicolumn{3}{|c|}{ Best AIC multivariate model } & \multirow[b]{2}{*}{$\mathbf{P}$} \\
\hline & Estimate & $\begin{array}{l}\text { Standard } \\
\text { Error }\end{array}$ & $\mathbf{P}$ & Estimate & $\begin{array}{l}\text { Standard } \\
\text { Error }\end{array}$ & \\
\hline \multicolumn{7}{|c|}{$\begin{array}{l}\text { Forest management (compare to Mixed } \\
\text { High Forest) }\end{array}$} \\
\hline Pure High Forest & 1.00 & 0.36 & $\begin{array}{l}0.0054 \\
(* *)\end{array}$ & 1.26 & 0.33 & $\begin{array}{l}0.0002 \\
(* \star \star)\end{array}$ \\
\hline Grass & 0.50 & 0.49 & 0.3105 & 0.42 & 0.47 & 0.3739 \\
\hline \multicolumn{7}{|c|}{ Forest type (compared to coniferous) } \\
\hline Deciduous & 0.53 & 0.33 & 0.1074 & - & - & - \\
\hline \multicolumn{7}{|c|}{ Undergrowth (compared to brambles) } \\
\hline Grass & -0.10 & 0.28 & 0.7013 & 0.16 & 0.25 & 0.5289 \\
\hline Moss & -1.19 & 0.57 & $\begin{array}{l}0.0356 \\
(*)\end{array}$ & -1.50 & 0.53 & $\begin{array}{l}0.0046 \\
(\star *)\end{array}$ \\
\hline Vegetation height & 0.40 & 0.16 & $\begin{array}{l}0.0111 \\
(*)\end{array}$ & - & - & - \\
\hline \multicolumn{7}{|c|}{ Soil Type (compared to loamy) } \\
\hline Loamy-Sand & 0.46 & 0.28 & 0.1058 & - & - & - \\
\hline \multicolumn{7}{|c|}{ Soil drainage (compared to excessive) } \\
\hline favourable & 0.86 & 0.29 & $\begin{array}{l}0.0029 \\
(* *)\end{array}$ & - & - & - \\
\hline Slope percentage & 0.05 & 0.13 & 0.7290 & - & - & - \\
\hline Distance to forest edge & -0.37 & 0.14 & $\begin{array}{l}0.0090 \\
(* *)\end{array}$ & - & - & - \\
\hline Random effects & & & & Variance & $\begin{array}{l}\text { Standard } \\
\text { Deviation }\end{array}$ & \\
\hline SU. Intercepts & & & & 0.59 & 0.77 & \\
\hline
\end{tabular}

[Insert Table 5 here]

\section{Discussion}

This study was the first estimate of DON at the Bois de Lauzelle. The mean density of questing nymphs was estimated at 6.61 nymphs per $10 \mathrm{~m}^{2}$, which is in the upper range of other studies in Belgium. Van Gestel et al. [10] found DON of 6.1 and 6.4 nymphs per $10 \mathrm{~m}^{2}$ in 2018 and 2019 in the Campine region of Belgium, higher than Ruyts et al. [82], with 4.05 nymphs per $10 \mathrm{~m}^{2}$ in the same region in 2013. In our study, DON was estimated based on consecutive drags compared to the single dragging used in other studies, which may explain the slightly higher density found. Moreover, we performed regular samplings throughout the year to capture the temporal variation of tick abundance, as recommended by Dobson [15] and Salomon et al. [83]. Tick density fluctuated with the local characteristics of the sampling sites, but they were active at the 
Bois de Lauzelle during the entire period of sampling. DON was highest in places with dense undergrowth, not easily accessible to forest visitors, like in [10], where DON was lower at benches, picknick tables and information boards, and adjacent to trails than in the forest interior. As in other peri-urban areas of Western Europe, ticks were more abundant in spring over summer, over fall (e.g. [70] in peri-urban green spaces in the United Kingdom). Body inspection should be always recommended to forest users during the season of tick activity.

B. burgdorferi prevalence was estimated at 3.37\%. Other studies in Belgium found higher nymphal prevalences: 17.8\% [84], $15.6 \%$ [82], 12\% [21], 9.1\% [8]. The latter study found a significant difference over short distances, ranging from 2.8 to 21.6\%. Hartemink et al. [85] also indicated high spatial variations in NIP in the Netherlands, ranging from 5-26\% between locations with similar forest types. In the Bois de Lauzelle, the estimated prevalence was also variable between places close to each other (1.21-11.99\%). In a forest stand, tick prevalence should therefore not be estimated from a single location. The low $B$. burgdorferi prevalence we found may relate to the lack of connections for wildlife with other forests, or to the presence of specific hosts and host composition [17].

Not all B. burgdorferi genospecies cause LB in domestic animals and humans, mainly B. burgdorferi s.s., B. afzelii, $B$. garinii, $B$. spielmanii and $B$. bavariensis $[23,24,86]$. Borrelia afzelii was the dominant genospecies identified in this study, which is consistent with other studies in Belgium (Additional file 5: S4). An older study found a different composition, with B. garinii being predominant (53\%) over B. afzelii (9\%) [87]. These differences may be due to changes in ecological conditions, species hosts or to the high variability among places, which makes local studies hardly comparable. Borrelia bavariensis and $B$. spielmanii, identified once in this study, are rare genospecies in Belgium. Our composition was similar to a recent meta-analysis in Western Europe, with $46.6 \%$ for $B$. afzelii, $23.8 \%$ for $B$. garinii, $11.4 \%$ for $B$. valaisiana, $10.2 \%$ for $B$. burgdorferi s.s., and $B$. bavariensis, $B$. spielmanii rarely detected [24]. Transmission cycles and dynamics of the different Borrelia genospecies are influenced by differences in serum sensitivity in animals parasitized by 1 . ricinus $[65,86]$. Borrelia afzelii and $B$. spielmanii are commonly associated with mammals, while other genospecies are hosted by sea birds and songbirds (B. garinii or B. valaisiana), or are generalist (B. burgdorferi s.s.) [19, 86, 88-91]. The dominance of $B$. afzelii over B. garinii may suggest that rodents (e.g., Apodemus sylvaticus) are the most important feeding hosts in the Bois de Lauzelle.

Francisella tularensis and Francisella-like bacteria were not detected in this study. Their absence was not surprising due to their low prevalence in ticks. Francisella tularensis was found in one tick from 69 ticks (1.45\%) in 2008 in the Sénart Forest (France), and it was not detected between 2009 and 2014 in the same region [92]. Coxiella burnetii was detected in three pools from SU.1 and SU.2. The prevalence of $C$. burnetii in questing I. ricinus in the Netherlands was $0.2 \%$ [43]. The prevalence of these pathogenic agents in ticks are currently not well known in Belgium. The $C$. burnetii Nine Mile strain (RSA 493), originally isolated in 1935 from the tick Dermacentor andersoni, was recently isolated in Belgium [40]. Public health significance of such low pathogen presence is difficult to assess with the number of pools tested in this study.

In our study, the acarological indicators (DON, TIP and DIN) were heterogeneous within a forest stand, as previously reported by Vourc'h et al. [7]. We found significant correlations between DON and DIN, but not between DON and TIP, similarly to Jouda et al. [93]. An absence of correlation between density of nymph and nymph infection prevalence is common in endemic areas [94], and has been reported elsewhere [7, 93, 95, 96]. Ruyts et al. [95] did not find inter-annual variation in NIP between 2009 and 2014 in Belgium forests and suggested that DON could be a good predictor of disease risk. It was confirmed by Hartemink et al. [85] who considered that DIN is mostly determined by DON, especially for variations through seasons, where DIN peaks along with DON. At the forest-stand level, results are more nuanced as they present different micro-environments influencing tick abundances and infection prevalence. For forest visitors, DON is a good indicator for LB risk, but further studies, considering more sampling sites and analysing more ticks, should confirm if Borrelia prevalences are different inside a forest stand. 
This study offers a first estimate of the heterogeneity of tick abundance in a forest stand. However, it is based on a limited number of sampling sites (7) and sampling events (17). Although these sites represent different micro-environments of the forests, further studies should consider more sites with the same characteristics to increase statistical power and limit the effects of samplings in a single location. The number of pools tested (221) was also low, especially for pathogens with low prevalence in ticks such as $C$. burnetii. The low Borrelia prevalence may also be explained because was found to be variable [21]. Infection prevalence in nymphs was estimated with 3'080 nymphs analysed individually in Ruyts et al. [95] while this study analysed 221 pools.

Consistently with other studies in Belgium $[8,11,95]$, we found higher DON under deciduous trees than under coniferous trees. More favourable conditions and a dense litter are often found in deciduous forests [19]. Li et al. [11] did not find a significant influence of soil texture on tick abundances comparing forests in Belgium, except a negative correlation with the percentage of clay. However, at a smaller scale, Guerra et al. [71] found more often I. scapularis ticks in loamy-sand and sandy soils than in loamy soils, consistently with our results. Ticks prefer humid upper soil layers, while excessive moisture may affect their winter survival and favour competitive organisms, such as fungi or nematodes [71]. Similarly, in this study, DON was higher in soils without an excessive drainage. Local humid conditions favourable for tick survival are also influenced by undergrowth. Several studies observed a negative effect of shrub clearing on the abundance of $I$. ricinus ticks but not on Borrelia infection [66, 97]. Borrelia garinii was predominant on shrub-clearing sites, indicating that these modified habitats may be preferred by birds compared to rodents [97]. However, in this study, the only Borrelia genospecies identified in shrub-clearing site (SU.5) was B. spielmanii, whose main host are mammals [90]. We found a positive effect of temperature on the number of questing ticks sampled. The influence of temperature is complex and not easily reproducible [98]. In this study, temperature was recorded in one location for the entire forest and at one meter above the litter, so not in the layer where I. ricinus shelter. Temperature was also measured punctually and did not reflect the range of temperatures encountered by the ticks through the year. The positive effect of temperature on tick abundance may be caused by an increase of tick activity at the time of the sampling [5]. Further studies should assess if a single measure of meteorological data is representative of the general conditions of the forest sites or mostly reflect specific conditions influencing tick activity during the samplings.

\section{Conclusion}

This study constitutes the first estimate of tick abundance in an intensively visited peri-urban forest in Belgium. The Bois de Lauzelle had high but variable tick abundance, with highest abundances in deciduous forests, located in sandy and loamysand soils covered by dense vegetation. Borrelia infected ticks were everywhere, but at relatively low prevalence. We identified six different Borrelia species with a typical composition for Western-Europe forests. Coxiella burnetii was present at very low prevalence, and $F$. tularensis was not detected.

The variability in tick abundance and Borrelia prevalence in a peri-urban forest was associated to two types of factors: (i) the micro-environment of the sampling site providing suitable habitats for ticks and hosts. (ii) the weather at the time of sampling influencing tick activity. These results thus confirm that the acarological risk for TBD is not homogeneous the in a peri-urban forest. Further understanding of this variability and its determinants may help identify high-hazard areas and, in heavily visited forests, identify management practices limiting the abundance of ticks in the most visited areas.

\section{Abbreviations}

DIA

density of infected adults

DIN

density of infected nymphs

DOA

Page 15/23 
density of adults

DON

density of nymphs

LB

Lyme borreliosis

SE

sampling event

SU

sampling unit

TBD

tick-borne diseases.

\section{Declarations}

Acknowledgements: The authors would like to acknowledge Elliott Wolter, who sampled the ticks during his master thesis. The authors also warmly acknowledge Martine Marin, Sebastien Landrain and Nihazi Saiti for their technical help performing the extractions, identifications, and sequencings.

Funding: This research received no external funding.

Availability of data and materials: The datasets supporting the conclusions of this article are included within the article and its supplementary information files.

Authors' contributions: SV and RR designed the conception of the work. MM performed the experiments for Francisella tularensis and Coxiella burnetii BK performed the experiments for Borrelia burgdorferi s.I., RR performed the experiments for tick identification and statistical analyses. RR wrote the first draft and the final version of the manuscript. SV, MM and BK substantively revised the manuscript. All authors read and approved the final manuscript.

Ethics approval and consent to participate: not applicable.

Consent for publication: not applicable.

Competing interests: The authors declare that they have no competing interests.

\section{References}

1. Jones KE, Patel NG, Levy MA, Storeygard A, Balk D, Gittleman JL, et al. Global trends in emerging infectious diseases. Nature. 2008;451:990-3.

2. Lambin EF, Tran A, Vanwambeke SO, Linard C, Soti V. Pathogenic landscapes: interactions between land, people, disease vectors, and their animal hosts. Int J Health Geogr. BioMed Central Ltd; 2010;9:54.

3. Dantas-Torres F, Chomel BB, Otranto D. Ticks and tick-borne diseases: A One Health perspective. Trends Parasitol. Elsevier Ltd; 2012;28:437-46.

4. de la Fuente J, Estrada-Pena A, Venzal JM, Kocan KM, Sonenshine DE. Overview: Ticks as vectors of pathogens that cause disease in humans and animals. Front Biosci. 2008;13:6938-46.

5. Medlock JM, Hansford KM, Bormane A, Derdakova M, Estrada-Peña A, George J-C, et al. Driving forces for changes in geographical distribution of Ixodes ricinus ticks in Europe. Parasit Vectors. 2013;6:1-11.

6. Estrada-Peña A, Venzal JM. Changes in habitat suitability for the tick Ixodes ricinus (Acari: Ixodidae) in Europe (19001999). Ecohealth. 2006;3:154-62. 
7. Vourc'h G, Abrial D, Bord S, Jacquot M, Masséglia S, Poux V, et al. Mapping human risk of infection with Borrelia burgdorferi sensu lato, the agent of Lyme borreliosis, in a periurban forest in France. Ticks Tick Borne Dis. Elsevier GmbH.; 2016;7:644-52.

8. Tack W, Madder M, Baeten L, Vanhellemont M, Gruwez R, Verheyen K. Local habitat and landscape affect Ixodes ricinus tick abundances in forests on poor, sandy soils. For Ecol Manage. Elsevier B.V.; 2012;265:30-6.

9. Ehrmann S, Liira J, Gärtner S, Hansen K, Brunet J, Cousins SAO, et al. Environmental drivers of Ixodes ricinus abundance in forest fragments of rural European landscapes. BMC Ecol. BioMed Central; 2017;17:1-14.

10. Van Gestel M, Verheyen K, Matthysen E, Heylen D. Danger on the track? Tick densities near recreation infrastructures in forests. Urban For Urban Green. Elsevier GmbH; 2021;59:126994.

11. Li S, Heyman P, Cochez C, Simons L, Vanwambeke SO. A multi-level analysis of the relationship between environmental factors and questing Ixodes ricinus dynamics in Belgium. Parasit Vectors. 2012;5:1-11.

12. Kiewra D, Stefańska-Krzaczek E, Szymanowski M, Szczepańska A. Local-scale spatio-temporal distribution of questing Ixodes ricinus L. (Acari: Ixodidae)-A case study from a riparian urban forest in Wrocław, SW Poland. Ticks Tick Borne Dis. 2017;8:362-9.

13. Estrada-Peña A, de la Fuente J. The ecology of ticks and epidemiology of tick-borne viral diseases. Antiviral Res. 2014;108:104-28.

14. Dobson ADM, Taylor JL, Randolph SE. Tick (Ixodes ricinus) abundance and seasonality at recreational sites in the UK: Hazards in relation to fine-scale habitat types revealed by complementary sampling methods. Ticks Tick Borne Dis. Elsevier GmbH.; 2011;2:67-74.

15. Dobson ADM. Ticks in the wrong boxes: assessing error in blanket-drag studies due to occasional sampling. Parasites and Vectors. 2013;6:344.

16. Vanwambeke SO, Sumilo D, Bormane A, Lambin EF, Randolph SE. Landscape predictors of tick-borne encephalitis in Latvia: land cover, land use, and land ownership. Vector-borne and zoonotic diseaes. 2010;10:497-506.

17. Ruiz-Fons F, Fernández-de-Mera IG, Acevedo P, Gortázar C, de la Fuente J. Factors driving the abundance of Ixodes ricinus ticks and the prevalence of zoonotic I. ricinus-borne pathogens in natural foci. Appl Environ Microbiol. 2012;78:2669-76.

18. Stanek G, Reiter M. The expanding Lyme Borrelia complex-clinical significance of genomic species? Clin Microbiol Infect. European Society of Clinical Infectious Diseases; 2011;17:487-93.

19. Gray JS. The ecology of ticks transmitting Lyme borreliosis. Exp Appl Acarol. 1998;22:249-58.

20. Strle F, Stanek G. Clinical manifestations and diagnosis of Lyme borreliosis. In: Lipsker, Dan, Jaulhac B, editor. Lyme Borreliosis- Biol Clin Asp. Basel: Karger; 2009. p. 51-110.

21. Kesteman T, Rossi C, Bastien P, Brouillard J, Avesani V, Olive N, et al. Prevalence and genetic heterogeneity of Borrelia burgdorferi sensu lato in Ixodes ticks in Belgium. Acta Clin Belg. 2010;65:319-22.

22. Obsomer V, Wirtgen M, Linden A, Claerebout E, Heyman P, Heylen D, et al. Spatial disaggregation of tick occurrence and ecology at a local scale as a preliminary step for spatial surveillance of tick-borne diseases: general framework and health implications in Belgium. Parasit Vectors. 2013;6:190.

23. van Dam AP, Kuiper H, Vos K, Widjojokusumo A, de Jongh BM., Spanjaard L, et al. Different genospecies of Borrelia burgdorferi are associated with distinct clinical manifestations of Lyme Borreliosis. Clin Infect Dis. 1993;17:708-17.

24. Strnad M, Hönig V, Ružek D, Grubhoffer L, Rego ROM. Europe-wide meta-analysis of Borrelia burgdorferi sensu lato prevalence in questing Ixodes ricinus ticks. Appl Environ Microbiol. 2017;83:1-16.

25. Steere AC, Strle F, Wormser GP, Hu LT, Branda JA, Hovius JWR, et al. Lyme borreliosis. Nat Rev Dis Prim. 2016;2.

26. Rauter C, Hartung T. Prevalence of Borrelia burgdorferi sensu lato in Ixodes ricinus ticks in Scandinavia. Appl Environ Microbiol. 2005;71:7203-16.

Page $17 / 23$ 
27. Lernout T, De Regge N, Tersago K, Fonville M, Suin V, Sprong H. Prevalence of pathogens in ticks collected from humans through citizen science in Belgium. Parasites and Vectors. BioMed Central; 2019;12:1-11.

28. Geebelen L, Van Cauteren D, Devleesschauwer B, Moreels S, Tersago K, Van Oyen H, et al. Combining primary care surveillance and a meta-analysis to estimate the incidence of the clinical manifestations of Lyme borreliosis in Belgium, 2015-2017. Ticks Tick Borne Dis. Elsevier; 2019;10:598-605.

29. Bleyenheuft C, Lernout T, Berger N, Rebolledo J, Leroy M, Robert A, et al. Epidemiological situation of Lyme borreliosis in Belgium, 2003 to 2012. Arch public Heal. Archives of Public Health; 2015;73:1-8.

30. WHO. World Health Organization guidelines on tularaemia: epidemic and pandemic alert and response [Internet]. 2007. p. 125. Available from: http://www.who.int/csr/resources/publications/WHO_CDS_EPR_2007_7.pdf

31. ECDC. Tularaemia factsheet [Internet]. 2017. Available from: https://www.ecdc.europa.eu/en/tularaemia/facts

32. Litzroth A, Delaere B, Mori M. Surveillance épidémiologique de la tularémie Francisella tularensis - 2017. Sciensano Rep. 2017.

33. Carvalho CL, Lopes de Carvalho I, Zé-Zé L, Núncio MS, Duarte EL. Tularaemia: A challenging zoonosis. Comp Immunol Microbiol Infect Dis. 2014;37:85-96.

34. Larson MA, Sayood K, Bartling AM, Meyer JR, Starr C, Baldwin J, et al. Differentiation of Francisella tularensis subspecies and subtypes. J Clin Microbiol. 2020;58:1-41.

35. Körner S, Makert GR, Ulbert S, Pfeffer M. The prevalence of Coxiella burnetii in hard ticks in Europe and their role in Q fever transmission revisited - a systematic review. Front Vet Sci. 2021;8:1-16.

36. Woldehiwet Z. Q fever (coxiellosis): Epidemiology and pathogenesis. Res Vet Sci. 2004;77:93-100.

37. Cutler SJ, Bouzid M, Cutler RR. Q fever. J Infect. 2007;54:313-8.

38. Mori M, Mertens K, Cutler SJ, Santos AS. Critical aspects for detection of Coxiella burnetii. Vector-Borne Zoonotic Dis. Mary Ann Liebert, Inc. 140 Huguenot Street, 3rd Floor New Rochelle, NY 10801 USA; 2017. p. 33-41.

39. Anderson A, Bijlmer H, Fournier P-E, Graves S, Hartzell J, Kersh GJ, et al. Diagnosis and management of Q fever-United States, 2013: recommendations from CDC and the Q Fever Working Group. Morb. Mortal. Wkly. Rep. Recomm. Reports. 2013.

40. Tomaiuolo S, Boarbi S, Fancello T, Michel P, Desqueper D, Grégoire F, et al. Phylogeography of Human and Animal Coxiella burnetii Strains: Genetic Fingerprinting of Q Fever in Belgium. Front Cell Infect Microbiol. 2021;10:1-15.

41. Litzroth A, van Esbroeck M, Mori M. Surveillance épidémiologique de la fièvre Q. Coxiella burnetii - 2017. 2017.

42. Duron O, Sidi-Boumedine K, Rousset E, Moutailler S, Jourdain E. The importance of ticks in Q fever transmission: what has (and has not) been demonstrated? Trends Parasitol. Elsevier Ltd; 2015;31:536-52.

43. Sprong H, Tijsse-Klasen E, Langelaar M, De Bruin A, Fonville M, Gassner F, et al. Prevalence of Coxiella burnetii in ticks after a large outbreak of Q Fever. Zoonoses Public Health. 2012;59:69-75.

44. Pacheco RC, Echaide IE, Alves RN, Beletti ME, Nava S, Labruna MB. Coxiella burnetii in ticks, Argentina. Emerg Infect Dis. 2013;19:344-6.

45. Ostfeld RS, Canham CD, Oggenfuss K, Winchcombe RJ, Keesing F. Climate, deer, rodents, and acorns as determinants of variation in Lyme-disease risk. PLoS Biol. 2006;4:1058-68.

46. Mysterud A, Easterday WR, Qviller L, Viljugrein H, Ytrehus B. Spatial and seasonal variation in the prevalence of Anaplasma phagocytophilum and Borrelia burgdorferi sensu lato in questing Ixodes ricinus ticks in Norway. Parasites and Vectors. 2013;6:1-8.

47. Ruiz-Fons F, Gilbert L. The role of deer as vehicles to move ticks, Ixodes ricinus, between contrasting habitats. Int $J$ Parasitol. 2010;40:1013-20.

48. Zeimes CB, Olsson GE, Hjertqvist M, Vanwambeke SO. Shaping zoonosis risk: landscape ecology vs. landscape attractiveness for people, the case of tick-borne encephalitis in Sweden. Parasit Vectors. 2014;7:370.

Page 18/23 
49. Wallonie. Site de Grand Intérêt Biologique (SGIB) - 219: Bois de Lauzelle. Site de Grand Intérêt Biologique (SGIB) [Internet]. La biodiversité en Wallonie. 2021 [cited 2021 Apr 30]. Available from: http://biodiversite.wallonie.be/fr/219bois-de-lauzelle.html?|DD=251659334\&IDC=1881

50. EEA. European Environment Agency - Site BE31006C0: Vallée de la Dyle à Ottignies [Internet]. Nat. 2000, Stand. Data Form. 2020. Available from: https://natura2000.eea.europa.eu/Natura2000/SDF.aspx?site=BE31006C0

51. Nyrhilä S, Sormunen JJ, Mäkelä S, Sippola E, Vesterinen EJ, Klemola T. One out of ten: low sampling efficiency of cloth dragging challenges abundance estimates of questing ticks. Exp Appl Acarol. Springer International Publishing; 2020;

52. Bord S, Druilhet P, Gasqui P, Abrial D, Vourc'h G. Bayesian estimation of abundance based on removal sampling under weak assumption of closed population with catchability depending on environmental conditions. Application to tick abundance. Ecol Modell. Elsevier B.V.; 2014;274:72-9.

53. Estrada-Pena A, Bouattour A, Camicas JL, Walker AR. Ticks of domestic animals in the Mediterranean Region: a guide to identification of species. University of Zaragoza, editor. Zaragoza; 2004.

54. Hillyard PD. Ticks of North-West Europe. The Natura. London; 1996.

55. Heylen D, De Coninck E, Jansen F, Madder M. Differential diagnosis of three common Ixodes spp. ticks infesting songbirds of Western Europe: Ixodes arboricola, I. frontalis and I. ricinus. Ticks Tick Borne Dis. Elsevier GmbH.; 2014;5:693-700.

56. Rousseau R, Vanwambeke SO, Boland C, Mori M. The isolation of culturable bacteria in Ixodes ricinus ticks of a Belgian peri-urban forest uncovers opportunistic bacteria potentially important for public health. Int J Environ Res Public Health. 2021;18:1-14.

57. Mori M, Boarbi S, Michel P, Bakinahe R, Rits K, Wattiau P, et al. In Vitro and In Vivo Infectious Potential of Coxiella burnetii: A Study on Belgian Livestock Isolates. PLoS One. 2013;8:1-9.

58. Versage JL, Severin DDM, Chu MC, Petersen JM. Development of a Multitarget Real-Time TaqMan PCR Assay for Enhanced Detection of Francisella tularensis in Complex Specimens. J Clin Microbiol. 2003;41:5492-9.

59. Michelet L, Delannoy S, Devillers E, Umhang G, Aspan A, Juremalm M, et al. High-throughput screening of tick-borne pathogens in Europe. Front Cell Infect Microbiol. 2014;4:1-13.

60. Cowling DW, Gardner IA, Johnson WO. Comparison of methods for estimation of individual- level prevalence based on pooled samples. 1999;39:211-25.

61. Gray JS, Dautel H, Estrada-Peña A, Kahl O, Lindgren E. Effects of climate change on ticks and tick-borne diseases in Europe. Interdiscip Perspect Infect Dis. 2009;2009:1-12.

62. Brownstein JS, Skelly DK, Holford TR, Fish D. Forest fragmentation predicts local scale heterogeneity of Lyme disease risk. Oecologia. 2005;146:469-75.

63. Diuk-Wasser MA, Vourc G, Cislo P, Hoen AG, Melton F, Hamer SA, et al. Field and climate-based model for predicting the density of host-seeking nymphal Ixodes scapularis, an important vector of tick-borne disease agents in the eastern United States. Glob Ecol Biogeogr. 2010;19:504-14.

64. Ehrmann S, Ruyts SC, Scherer-Lorenzen M, Bauhus J, Brunet J, Cousins SAO, et al. Habitat properties are key drivers of Borrelia burgdorferi (s.I.) prevalence in Ixodes ricinus populations of deciduous forest fragments. Parasites and Vectors. Parasites \& Vectors; 2018;11:1-15.

65. Van Overbeek L, Gassner F, Van Der Plas CL, Kastelein P, Nunes-Da Rocha U, Takken W. Diversity of Ixodes ricinus tickassociated bacterial communities from different forests. FEMS Microbiol Ecol. 2008;66:72-84.

66. Tack W, Madder M, Baeten L, Vanhellemont M, Verheyen K. Shrub clearing adversely affects the abundance of Ixodes ricinus ticks. Exp Appl Acarol. 2013;60:411-20.

67. Vanwambeke SO, Van doninck J, Artois J, Davidson RK, Meyfroidt P, Jore S. Forest classes and tree cover gradient: tick habitat in encroached areas of southern Norway. Exp Appl Acarol. Springer International Publishing; 2016;68:375-85.

Page 19/23 
68. Lauterbach R, Wells K, O’Hara RB, Kalko EK V, Renner SC. Variable strength of forest stand attributes and weather conditions on the questing activity of Ixodes ricinus ticks over years in managed forests. PLoS One. 2013;8:e55365.

69. Allan BF, Keesing F, Ostfeld RS. Effect of forest fragmentation on Lyme Disease risk. Conserv Biol. 2003;17:267-72.

70. Hansford KM, Fonville M, Gillingham EL, Coipan EC, Pietzsch ME, Krawczyk Al, et al. Ticks and Borrelia in urban and peri-urban green space habitats in a city in southern England. Ticks Tick Borne Dis. Elsevier GmbH.; 2017;8:353-61.

71. Guerra M, Walker E, Jones C, Paskewitz S, Cortinas MR, Stancil A, et al. Predicting the Risk of Lyme Disease: Habitat Suitability for Ixodes scapularis in the North Central United States. Emerg Infect Dis. 2002;8:289-97.

72. SPW. Services Publics de Wallonie - Carte des Principaux Types de Sols de Wallonie - 1/250000 [Internet]. Serv. Publics Wallonie. 2005 [cited 2021 May 29]. Available from: https://geoportail.wallonie.be/catalogue/64bbc088-367c485c-bd7c-d2d08baedf9d.html

73. Paradis E, Schliep K. ape 5.0: an environment for modern phylogenetics and evolutionary analyses in $\{R\}$. Bioinformatics. 2019. p. 526-8.

74. Oksanen J, Blanchet FG, Friendly M, Kindt R, Legendre P, McGlinn D, et al. vegan: Community Ecology Package. 2020.

75. Hill MO. Diversity and Evenness: A Unifying Notation and Its Consequences. Ecology. 1973;54:427-32.

76. Bates D, Mächler M, Bolker B, Walker S. Fitting linear mixed-effects models using \{lme4\}. J. Stat. Softw. 2015. p. 1-48.

77. Yirga AA, Melesse SF, Mwambi HG, Ayele DG. Negative binomial mixed models for analyzing longitudinal CD4 count data. Sci Rep. Nature Publishing Group UK; 2020;10:1-15.

78. Dormann CF, Elith J, Bacher S, Buchmann C, Carl G, Carr G, et al. Collinearity: a review of methods to deal with it and a simulation study evaluating their performance. Ecography (Cop). 2013;36:27-46.

79. Jackman S. \{pscl\}: Classes and Methods for $\{R\}$ Developed in the Political Science Computational Laboratory. Sydney, New South Wales, Australia; 2020.

80. Zuur AF, leno EN, Walker NJ, Saveliev AA, Smith GM. Mixed effects models and extensions in ecology with R. Springer Sci. Bus. Media. 2009.

81. R Core Team. R: A Language and Environment for Statistical Computing; R Foundation for Statistical Computing. Vienna, Austria: R Foundation for Statistical Computing; 2020.

82. Ruyts SC, Ampoorter E, Coipan EC, Baeten L, Heylen D, Sprong H, et al. Diversifying forest communities may change Lyme disease risk: Extra dimension to the dilution effect in Europe. Parasitology. 2016;143:1310-9.

83. Salomon J, Hamer SA, Swei A. A beginner's guide to collecting questing hard ticks (acari: ixodidae): A standardized tick dragging protocol. J Insect Sci. 2020;20:1-8.

84. Heylen D, Lasters R, Adriaensen F, Fonville M, Sprong H, Matthysen E. Ticks and tick-borne diseases in the city: Role of landscape connectivity and green space characteristics in a metropolitan area. Sci Total Environ. Elsevier B.V; 2019;670:941-9.

85. Hartemink N, van Vliet AJH, Gort G, Gassner F, Jacobs F, Fonville M, et al. Seasonal patterns and spatial variation of Borrelia burgdorferi (sensu lato) infections in Ixodes ricinus in the Netherlands. Parasites and Vectors. BioMed Central; 2021;14:1-16.

86. Kurtenbach K, De Michelis S, Etti S, Schäfer SM, Sewell HS, Brade V, et al. Host association of Borrelia burgdorferi sensu lato - The key role of host complement. Trends Microbiol. 2002;10:74-9.

87. Misonne MC, Van Impe G, Hoet PP. Genetic heterogeneity of Borrelia burgdorferi sensu lato in Ixodes ricinus ticks collected in belgium. J Clin Microbiol. 1998;36:3352-4.

88. Pedersen BN, Jenkins A, Kjelland V. Tick-borne pathogens in Ixodes ricinus ticks collected from migratory birds in southern Norway. PLoS One. 2020;15:1-13.

89. Comstedt P, Bergström S, Olsen B, Garpmo U, Marjavaara L, Mejlon H, et al. Migratory passerine birds as reservoirs of Lyme borreliosis in Europe. Emerg Infect Dis. 2006;12:1307.

Page 20/23 
90. Heylen D, Matthysen E, Fonville M, Sprong H. Songbirds as general transmitters but selective amplifiers of Borrelia burgdorferi sensu lato genotypes in Ixodes rinicus ticks. Environ Microbiol. 2014;16:2859-68.

91. Hanincova K, Schäfer SM, Etti S, Sewell HS, Taragelová V, Ziak D, et al. Association of Borrelia afzelii with rodents in Europe. Parasitology. 2003;126:11-20.

92. Paul REL, Cote M, Le Naour E, Bonnet SI. Environmental factors influencing tick densities over seven years in a French suburban forest. Parasit Vectors. Parasites \& Vectors; 2016;9:309.

93. Jouda F, Perret J-L, Gern L. Density of questing Ixodes ricinus nymphs and adults infected by Borrelia burgdorferi sensu lato in Switzerland: Spatio-temporal pattern at a regional scale. Vector borne zoonotic Dis. 2004;4:23-32.

94. Randolph SE. The shifting landscape of tick-borne zoonoses: tick-borne encephalitis and Lyme borreliosis in Europe. Philos Trans R Soc London B Biol Sci. 2001;356:1045-56.

95. Ruyts SC, Tack W, Ampoorter E, Coipan EC, Matthysen E, Heylen D, et al. Year-to-year variation in the density of Ixodes ricinus ticks and the prevalence of the rodent-associated human pathogens Borrelia afzelii and B. miyamotoi in different forest types. Ticks Tick Borne Dis. Elsevier; 2017;9:141-5.

96. James MC, Bowman AS, Forbes KJ, Lewis F, McLeod JE, Gilbert L. Environmental determinants of Ixodes ricinus ticks and the incidence of Borrelia burgdorferi sensu lato, the agent of Lyme borreliosis, in Scotland. Parasitology. 2013;140:237-46.

97. Hubálek Z, Halouzka J, Juřicová Z, Šikutová S, Rudolf I. Effect of forest clearing on the abundance of Ixodes ricinus ticks and the prevalence of Borrelia burgdorferi s.I. Med Vet Entomol. 2006;20:166-72.

98. Boyard C, Barnouin J, Bord S, Gasqui P, Vourc'h G. Reproducibility of local environmental factors for the abundance of questing Ixodes ricinus nymphs on pastures. Ticks Tick Borne Dis. 2011;2:104-10.

\section{Figures}




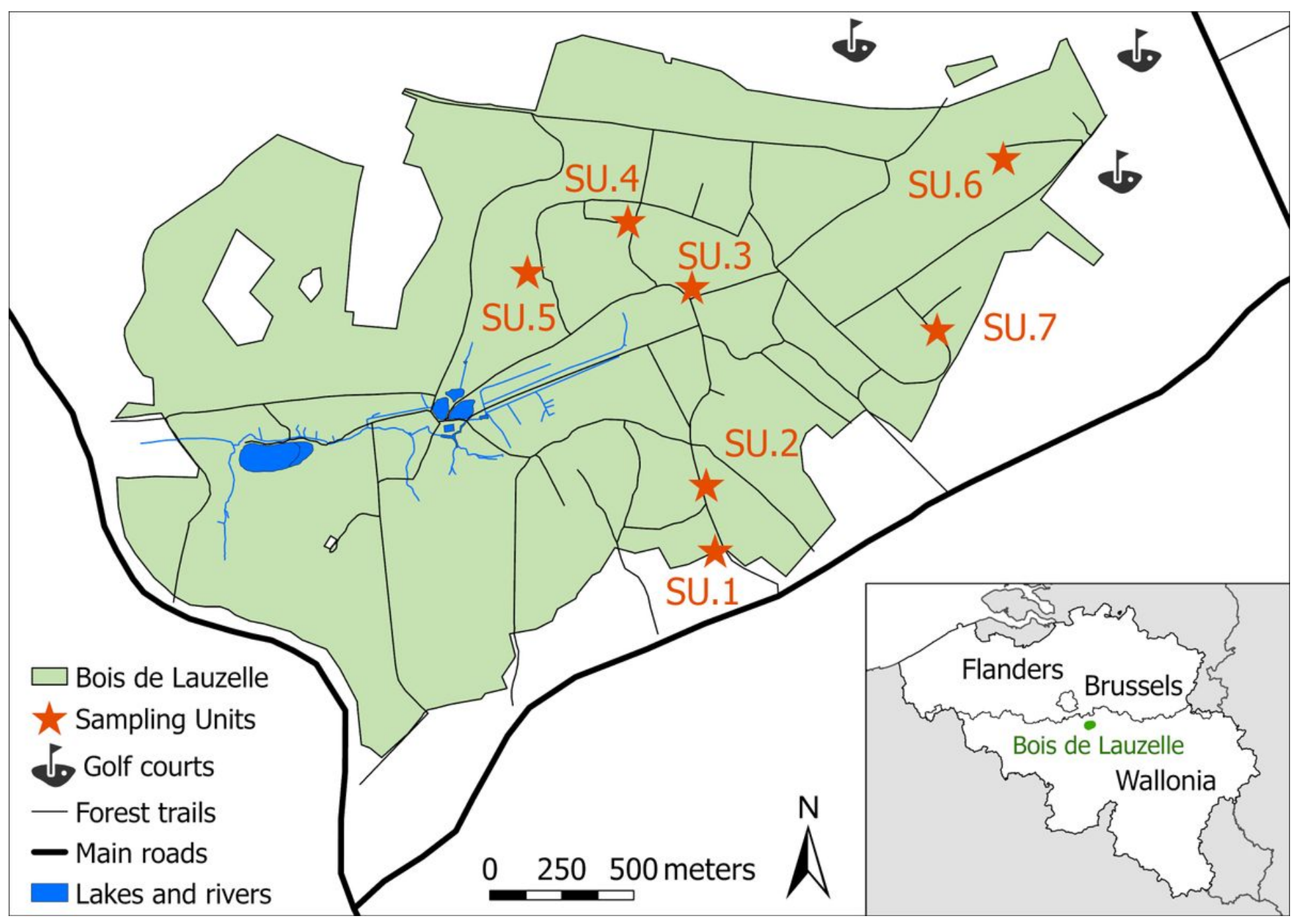

Figure 1

Location of the seven sampling units (SU) in the Bois de Lauzelle. 


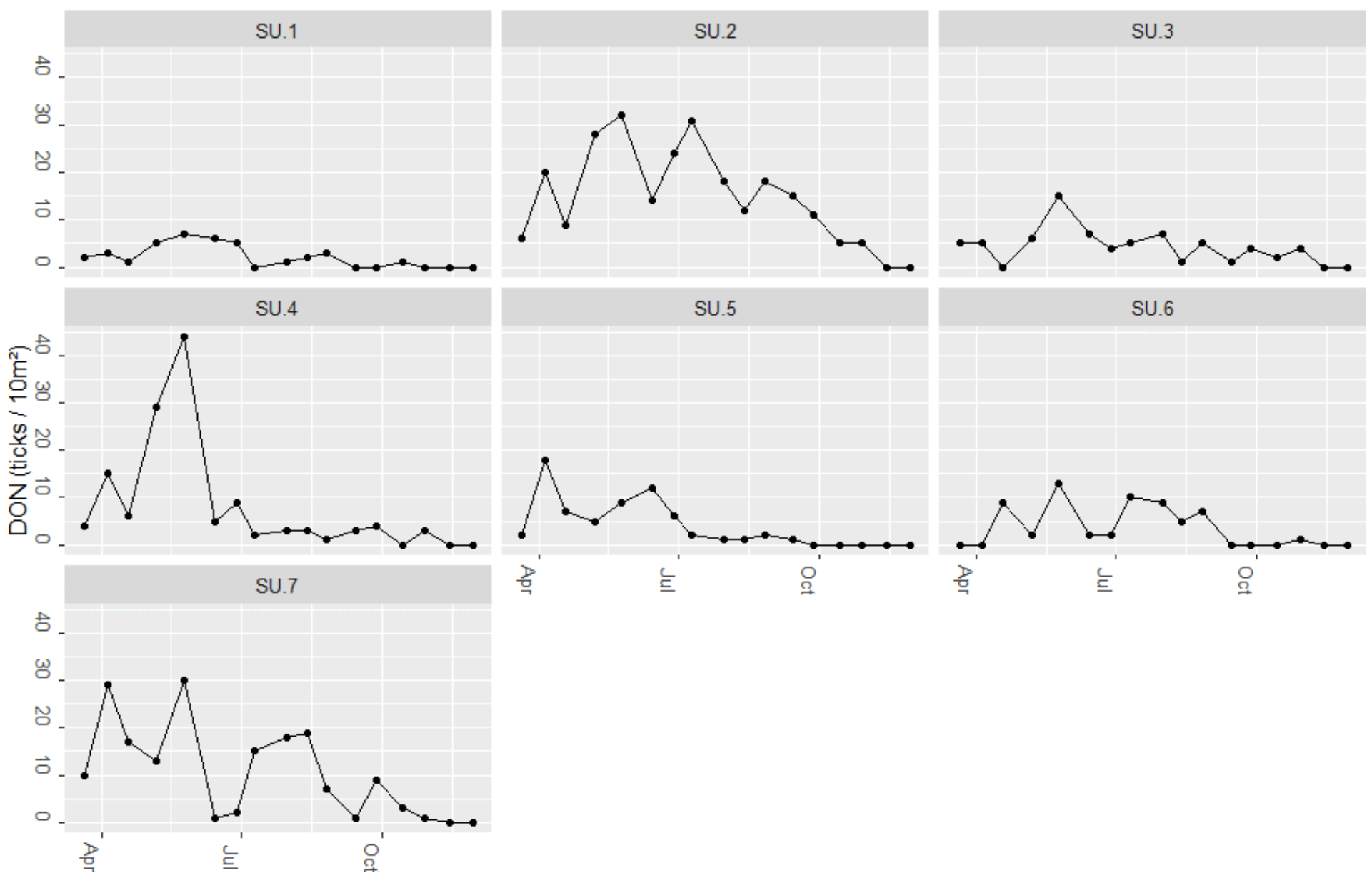

\section{Figure 2}

DON evolution by SU from March to November. Each dot constitutes an observation. DON stands for density of nymphs and SU for sampling unit.

\section{Supplementary Files}

This is a list of supplementary files associated with this preprint. Click to download.

- TTBPBDLSupplementaryMaterials1SUPictures.docx

- TTBPBDLSupplementaryMaterials2DataBaseSampling.ods

- TTBPBDLSupplementaryMaterials3DataPools.ods

- TTBPBDLSupplementaryMaterials4Stats.docx

- TTBPBDLSupplementaryMaterials5BorreliaBelgium.xlsx

- TTBDBDLGraphicalAbstract.tif 